\title{
Qualitative and quantitative analysis of solar hydrogen generation literature from 2001 to 2014
}

\author{
Mohammad Reza Maghami ${ }^{1} \cdot$ Shahin navabi asl ${ }^{2} \cdot$ \\ Mohammad esmaeil Rezadad ${ }^{3} \cdot$ Nader Ale Ebrahim $^{4}$. \\ Chandima Gomes ${ }^{1}$
}

Received: 12 July 2015/Published online: 9 September 2015

(c) Akadémiai Kiadó, Budapest, Hungary 2015

\begin{abstract}
Solar hydrogen generation is one of the new topics in the field of renewable energy. Recently, the rate of investigation about hydrogen generation is growing dramatically in many countries. Many studies have been done about hydrogen generation from natural resources such as wind, solar, coal etc. In this work we evaluated global scientific production of solar hydrogen generation papers from 2001 to 2014 in any journal of all the subject categories of the Science Citation Index compiled by Institute for Scientific Information (ISI), Philadelphia, USA. Solar hydrogen generation was used as keywords to search the parts of titles, abstracts, or keywords. The published output analysis showed that hydrogen generation from the sun research steadily increased over the past 14 years and the annual paper production in 2013 was about three times 2010-paper production. The number of papers considered in this research is 141 which have been published from 2001 to this date. There are clear distinctions among author keywords used in publications from the five most high-publishing countries such as USA, China, Australia, Germany and India in solar hydrogen studies. In order to evaluate this work quantitative and qualitative analysis methods were used to the development of global scientific production in a specific research field. The analytical results eventually provide several key findings and consider the overview hydrogen production according to the solar hydrogen generation.
\end{abstract}

Electronic supplementary material The online version of this article (doi:10.1007/s11192-015-1730-3) contains supplementary material, which is available to authorized users.

Mohammad Reza Maghami

mr.maghami@gmail.com

1 Department of Electrical and Electronic Engineering, Faculty of Engineering, Universiti Putra Malaysia, 43400 Serdang, Malaysia

2 Department of Electrical and Electronic Engineering, Faculty of Engineering, Islamic Azad University, Damghan Branch, Damghan, Iran

3 Department of Mechanical Engineering, Faculty of Engineering, University of Malaya (UM), 50603 Kuala Lumpur, Malaysia

4 Research Support Unit, Centre of Research Services, Institute of Research Management and Monitoring (IPPP), University of Malaya (UM), Kuala Lumpur, Malaysia 
Keywords Solar hydrogen generation · Hydrogen generation · Water splitting · Hydrogen literature

\section{Introduction}

Today's energy shortage and environment pollution are the two issues that we face in this century (Maghami et al. 2014, 2015), and due to these reasons, the industry for producing renewable energy is growing (Kotler 2011; Motlagh et al. 2015). One of the important methods of energy generations from renewable energies is solar hydrogen (Momirlan and Veziroglu 2002; Bak et al. 2002; Barbir 2005; Momirlan and Veziroglu 2005; Zhang et al. 2007; Sherif et al. 2005; Veziroglu 2008; Nadal and Barbir 1996; El-Bassuoni et al. 1982; Sopian et al. 1996). As a renewable and clean source, solar energy has gained significant attention in recent years for the high demand for low energy at a competitive cost and with zero emissions (Nadal and Barbir 1996; Dincer 2011; Eriksson et al. 2006; Barbir 2012; Fakioğlu et al. 2004). Since solar energy is inherently variable and intermittent, one of the main obstacles to their widespread use in providing reliable electric power is the requirement to store the electrical energy (Gorensek and Forsberg 2009; Xiong et al. 2002).

Using hydrogen for energy storage system is an attractive option which is surplus electric power that is obtained from a photovoltaic panel that moves to an electrolyser to generate hydrogen stored by water splitting and then, the stored hydrogen gas is supplied to a fuel cell during times of low or no sunlight to compensate the supply shortfalls (Linkous 2001; Ghosh et al. 2003; Satyapal et al. 2007; Winter 1987).

Considerable research has been done on the different components of solar-hydrogen system for RAPS, namely the solar PV panel, electrolyser, hydrogen storage and fuel cell (Bak et al. 2002; Larminie et al. 2003; Dicks 1996). Shabaniet and Andrews considered the PEM fuel cells in experimental investigation to supply heat and power in PAPS. The economic advantages of using the fuel cell heat to improve the LPG hot water system over a 30-year appraisal period is estimated to be about $15 \%$ of the total capital cost of the solar hydrogen system. John Andrews and Xin Xu Dou studied about designing a control unit for a solar-hydrogen system for remote area power supply in 2010 in Australia, and they found that all requirements started earlier will be carried into the simulation (Matlab) to establish the best control algorithms. When they designed the optimum control, system was tested in computer. The experience system was designed to measured real performance.

An overview of experimental and demonstration systems are described in the literature. However, there is still a need for more work on the general control unit for these systems as well as reducing the total cost of the system, extending the lifespan of components, and safety assurance. Some research investigations have been done on design and test of preferred options for splitting the Photovoltaic output between final load and electrolyser as needed by the instantaneous system conditions, as well as achieve high power transmission efficiency to the combined final load and electrolyser. Figure 1 shows that solar cells absorb light from the sun. Then, they transfer it to the electrolyzer in order to split water into hydrogen and oxygen (van de Krol et al. 2008).

In this paper, we consider solar hydrogen literature. Since, hydrogen is a relatively broad term, it can refer to a number of different technologies, processes, and methods. It has many applications related to energy, smart grid, energy management, energy policy, telecommunications, and business. For this reason, hydrogen applications can be the 
Fig. 1 Solar cell inserts electric to the electrolyzer

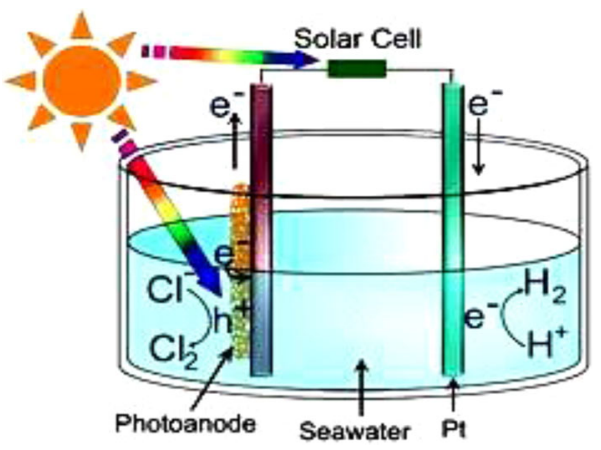

foundation for many location-enabled services that rely on analysis, visualization and dissemination of results for collaborative decision-making. The aims of this paper is to analysis qualities and quantities of the researches done during the last two decade.

\section{Methodology and materials}

All documents used in this study were accessed from the database of the Science Citation Index (SCI), obtained by subscription from the ISI, Web of Science, Philadelphia, PA, USA. In this study, we only focus on papers published after 2001, because there was less data regarding solar hydrogen before that year. To shed the light on solar hydrogen trends and contributions, quantitative analysis and qualitative analysis are conducted in this research.

\section{Quantitative analysis}

For the quantitative analysis, the SCI are systematically searched for solar hydrogenrelated materials published from 2001 to April 2014. Selected documents included "Solar hydrogen generation' in the title, abstract, or keywords. Analyzed parameters included authorship, patterns of international collaboration, journal, language, document type, research address, number of times cited, and reprint author's address. Citation analysis was based primarily on the impact factor as defined by the journal citation reports (JCR) and on citations per publications (CPP), which are used to assess the impact of a journal relative to the entire field. It is defined as the ratio of the number of citations the publication has received to since it is published.

\section{Qualitative analysis}

For qualitative analysis the historical method was used. The historical method proposes that historical phenomena can be rich and complex; we can gain a better understanding by reviewing and investigating the times, places and contexts in which events occur and develop. The historical method was employed in investigating the initiation and development of solar hydrogen as documented in publications in the SCI from 2001 to April 2014. For a longitudinal literature review, we employed historical review method to 
explore solar hydrogen technological trend. Based on this review, we forecast possible future developments.

\section{Result and discussion}

\section{Number of publication and citation among year}

According to the data obtained from ISI Web of Knowledge as presented in Fig. 2, it shows the number of publications about solar hydrogen generation in a period of 15 years. From the Fig. 2, it is concluded that the research about this topic have just been published from 2000. Therefore, it is observed that research in solar hydrogen is extensively new topic. In addition, there were fewer than six paper published before 2006 and only after 2008 this research became a hot topic among researchers. Obviously, in 2013 there was rapid increase in number of publications and citations. Although in 2008 the number of publications was fewer than 2007, however, the citation trend shown in Fig. 3 indicates that the number of citations is very close to the one in 2007. Thus, the promising future of solar hydrogen is guaranteed.

The total citation count was obtained from SCI, web of science, on April 20, 2014. When the SCI search process for this study was conducted, the total number of times that a particular paper had been cited by all journals listed in the database was shown. The title of the most highly cited paper published in this area since 2001 is "Estimating Photo-electrochemical hydrogen generation". Materials-related aspects by Bak, T, received by International Journal of Hydrogen Energy 2002, which has been cited for 549 times. Among the top ten most cited papers, the USA contributed 4 of them, followed by Australia, which produced two articles and China, Armenia, Switzerland and Israel with one articles each. It is worth mentioning that papers related to Energy had a relatively higher number of citations than many other scientific fields. Nevertheless, there still exist a biasness on citation analysis due to differences of the publication year. It must be pointed out that the number of citations in single article was highly correlated with the length of time since its publication. As it can be seen in Fig. 3, the average number of times that the paper receives citations increases as the time goes on since its publication. Therefore, average number of citation per year was used to compare the papers in different years.

From 2005 to 2014, the annual number of Citation articles according to Fig. 4 the scatter plot was growing at a stable rate. The fit produced a high determination coefficient

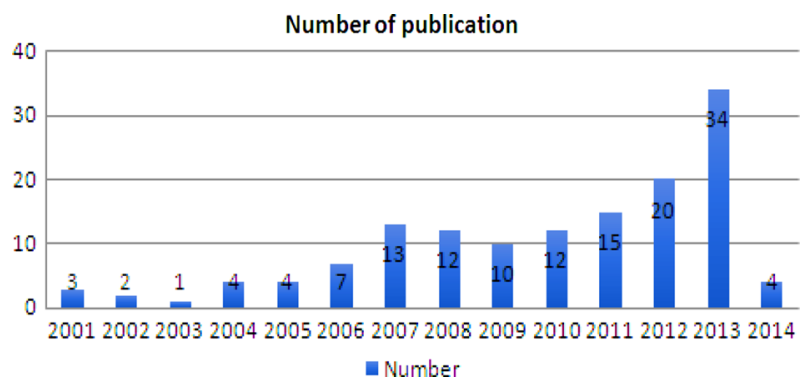

Fig. 2 Number of paper published among year is displays 


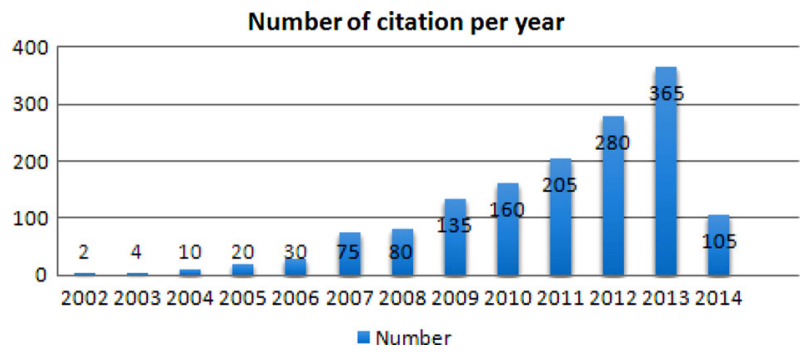

Fig. 3 Number of citation among year is displays

Fig. 4 Scatter plot for solar hydrogen citation are displays

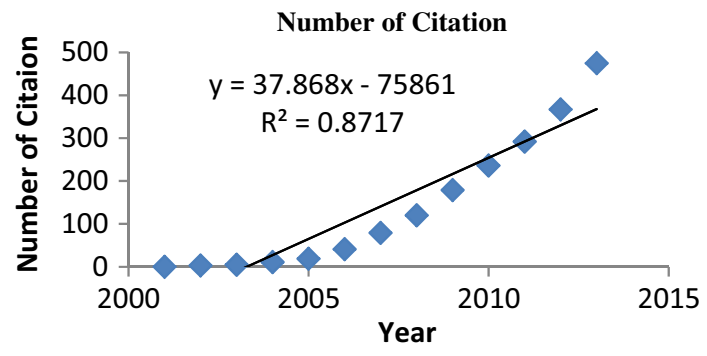

from the collected data $(R 2=0.8717)$. The best fit to forecast solar hydrogen generation was found to be:

$$
y=37.868 x-75861
$$

Where $y$ is the article number and $x$ is the number of years since 2001. Extrapolating from the model, the number of articles about forest ecology in the following years could be forecasted.

\section{Distribution by source titles, research area and web of science categories}

According to Table 1, most of the papers in this field are published in International Journal of Hydrogen Energy, which has ranked 16 in categories of energy fuel, with 32 papers. Following by abstracts the best publisher in field is American Chemical Society with nine papers. According to the fourth column of Table 1, Energy fuel with 73 papers, followed by Chemistry with 70 and electrochemistry with 41 are the three best categories.

According to distribution by web of science categories, Energy fuel, chemistry, and electrochemistry are the three categories, which publish most of the papers, followed by chemistry and material. Figure 5, shows more than $70 \%$ of those papers published in those three categories.

\section{Top ten papers in solar hydrogen generation}

The most frequently cited articles for the period between 2003 and 2014 are presented in Table 2. Five of the most frequently cited articles were published in International Journal of Hydrogen Energy. Six of the most frequently cited articles (among them the top six listings) originated in the USA and Australia, and one each in, China, Armenia, 
Table 1 Distribution by source titles and Research area

\begin{tabular}{|c|c|c|c|c|c|}
\hline Source titles & $\mathrm{N}$ & $\begin{array}{l}\% \text { of } \\
141\end{array}$ & Research areas & $\mathrm{N}$ & $\begin{array}{l}\% \text { of } \\
141\end{array}$ \\
\hline International Journal of Hydrogen Energy & 32 & 22.6 & Energy Fuels & 73 & 51.77 \\
\hline $\begin{array}{l}\text { Abstracts of Papers of the American } \\
\text { Chemical Society }\end{array}$ & 9 & 6.38 & Chemistry & 70 & 49.64 \\
\hline Journal of Power Sources & 5 & 3.54 & Electrochemistry & 41 & 29.07 \\
\hline Solar Energy & 5 & 3.54 & Engineering & 29 & 20.56 \\
\hline AIP Conference Proceedings & 4 & 2.83 & Materials Science & 25 & 17.73 \\
\hline Energy Environmental Science & 4 & 2.83 & Physics & 21 & 14.89 \\
\hline Applied Physics Letters & 3 & 2.12 & $\begin{array}{l}\text { Science Technology Other } \\
\text { Topics }\end{array}$ & 17 & 12.05 \\
\hline International Journal of Energy Research & 3 & 2.12 & $\begin{array}{l}\text { Environmental Sciences } \\
\text { Ecology }\end{array}$ & 10 & 7.092 \\
\hline Journal of Physical Chemistry C & 3 & 2.12 & $\begin{array}{l}\text { Nuclear Science } \\
\text { Technology }\end{array}$ & 3 & 2.12 \\
\hline \multirow[t]{2}{*}{ ESA Special Publications } & 2 & 1.41 & Construction Building & 2 & \\
\hline & & & Technology & 1.41 & \\
\hline
\end{tabular}

$N$ Number of Publications

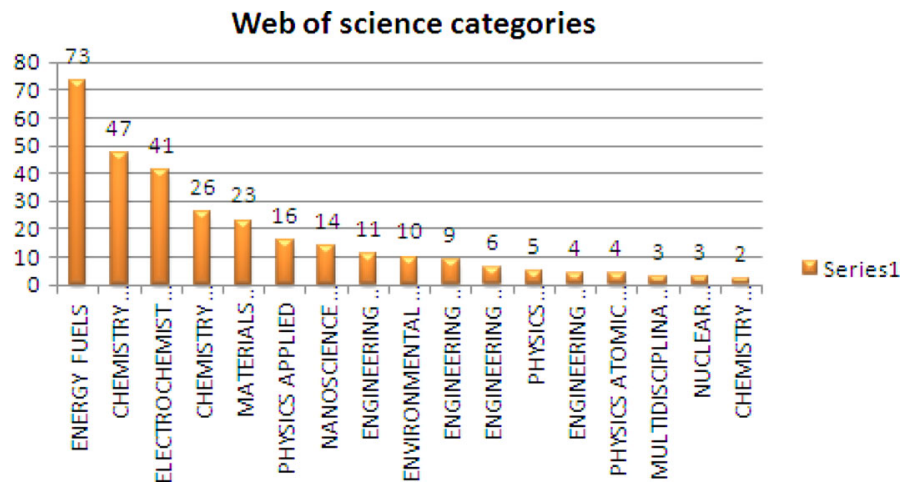

Fig. 5 Distribution by web of science categories

Switzerland, and Israel respectively. The two articles with the most citations (549 and 135) come from International Journal of Hydrogen Energy and Nano letter. An interesting aspect, presented as the fourth column in Table 2, is the average number of citations per year (AC). Although this observation is not consistent, it appears that the number of citations per year tends to increase with the number of years since publication. Pointing to a possible snowball effect when it comes to the acceptance of novel research results published papers involved international collaborations. A summary of the ten most frequently cited articles revealed that six papers originated in the United States, and four were published in International Journal of Hydrogen Energy, which has one of the highest impact factors in the category of energy. The three journals with the most articles in this category were Solar Energy, Energy and Environmental Science and Journal of Power Sources. 
Table 2 Top high citation papers in field solar hydrogen generation

\begin{tabular}{|c|c|c|c|c|c|}
\hline Author & Title & $\mathrm{J}$ & $\mathrm{C}$ & $\mathrm{NC}$ & $\mathrm{AC}$ \\
\hline Bak (2002) & $\begin{array}{l}\text { Photo electrochemical hydrogen } \\
\text { generation from water using solar } \\
\text { energy. materials-related aspects }\end{array}$ & $\begin{array}{l}\text { International } \\
\text { Journal of } \\
\text { Hydrogen } \\
\text { Energy }\end{array}$ & Australia & 549 & 42.23 \\
\hline $\begin{array}{l}\text { Hensel } \\
\quad(2010)\end{array}$ & $\begin{array}{l}\text { Synergistic effect of cdse quantum dot } \\
\text { sensitization and nitrogen doping of } \\
\text { TIO2 nanostructures for photo } \\
\text { electrochemical solar hydrogen } \\
\text { generation }\end{array}$ & Nano Letters & USA & 135 & 27 \\
\hline $\begin{array}{l}\text { Aroutiounian } \\
\text { (2005) }\end{array}$ & $\begin{array}{l}\text { Metal oxide photo electrodes for } \\
\text { hydrogen generation using solar } \\
\text { radiation driven water splitting }\end{array}$ & Solar Energy & Armenia & 134 & 13.4 \\
\hline Raja (2006a) & $\begin{array}{l}\text { Photo electrochemical hydrogen } \\
\text { generation using band-gap modified } \\
\text { nanotubular titanium oxide in solar light }\end{array}$ & $\begin{array}{l}\text { Journal of Power } \\
\text { Sources }\end{array}$ & USA & 71 & 7.89 \\
\hline Raja (2006b) & $\begin{array}{l}\text { Determination of photo conversion } \\
\text { efficiency of nanotubular titanium oxide } \\
\text { photo electrochemical cell for solar } \\
\text { hydrogen generation }\end{array}$ & $\begin{array}{l}\text { Journal of Power } \\
\text { Sources }\end{array}$ & USA & 66 & 7.33 \\
\hline $\begin{array}{l}\text { Gibson } \\
(2008)\end{array}$ & $\begin{array}{l}\text { Optimization of solar powered hydrogen } \\
\text { production using photovoltaic } \\
\text { electrolysis devices }\end{array}$ & $\begin{array}{l}\text { International } \\
\text { Journal of } \\
\text { Hydrogen } \\
\text { Energy }\end{array}$ & USA & 56 & 8 \\
\hline Licht (2001) & $\begin{array}{l}\text { Over } 18 \% \text { solar energy conversion to } \\
\text { generation of hydrogen fuel; theory and } \\
\text { experiment for efficient solar water } \\
\text { splitting }\end{array}$ & $\begin{array}{l}\text { International } \\
\text { Journal of } \\
\text { Hydrogen } \\
\text { Energy }\end{array}$ & Israel & 54 & 3.86 \\
\hline Luo (2011) & $\begin{array}{l}\text { Solar hydrogen generation from seawater } \\
\text { with a modified BIVO4 photoanode }\end{array}$ & $\begin{array}{l}\text { Energy and } \\
\text { environmental } \\
\text { science }\end{array}$ & China & 53 & 13.25 \\
\hline $\begin{array}{l}\text { Z'graggen } \\
\text { et al. (2006) }\end{array}$ & $\begin{array}{l}\text { Hydrogen production by steam } \\
\text { gasification of petroleum coke using } \\
\text { concentrated solar power-II-Reactor } \\
\text { design, testing, and modeling }\end{array}$ & $\begin{array}{l}\text { International } \\
\text { Journal of } \\
\text { Hydrogen } \\
\text { Energy }\end{array}$ & Switzerland & 51 & 5.67 \\
\hline Paul (2008) & $\begin{array}{l}\text { Optimal coupling of PV arrays to PEM } \\
\text { electrolysers in solar-hydrogen systems } \\
\text { for remote area power supply }\end{array}$ & $\begin{array}{l}\text { International } \\
\text { Journal of } \\
\text { Hydrogen } \\
\text { Energy }\end{array}$ & Australia & 42 & 6 \\
\hline
\end{tabular}

$J$ Journal, $C$ Country, $N C$ Number of citation, $A C$ Average citation

\section{Distribution by document type and language}

The majority of publications on solar hydrogen generation research is done in English. One interesting finding is the increase in solar hydrogen generation research since 2010; it is clear that Solar Hydrogen Generation or Solar Hydrogen Power study is becoming ever more important around world. According to Fig. 6, it is clear more than $97(68 \%)$ of papers published is articles, followed by $35(24.8 \%)$ proceedings paper, abstract with $6 \%$, amd review with $2 \%$. 


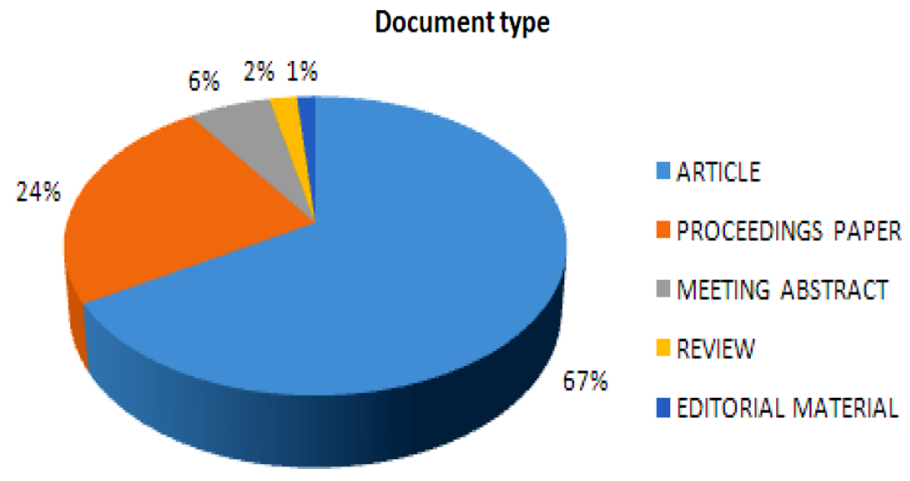

Fig. 6 Type of document in ISI web of knowledge

Table 3 Distribution by country/territory and institution name

\begin{tabular}{lllr}
\hline Countries/ & N & Organizations-enhanced & N \\
\hline USA & 42 & United States Department Of Energy Doe & 10 \\
China & 16 & University Of California System & 7 \\
Australia & 13 & Chinese Academy Of Sciences & 6 \\
Germany & 12 & Royal Melbourne Institute Of Technology RMIT & 5 \\
India & 10 & University Of California Santa Cruz & 5 \\
Japan & 10 & University Of New South Wales & 5 \\
Spain & 9 & Anna University & 4 \\
England & 7 & Anna University Chennai & 4 \\
South Korea & 6 & Argonne National Laboratory & 4 \\
Switzerland & 5 & National Taiwan University & 4 \\
\hline
\end{tabular}

\section{Distribution by countries and organization}

Table 3 shows USA is at the top with 42 (20.20\%), followed by China, with $16(15.33 \%)$. Australia ranks third, with $13(6.13 \%)$. Germany, India, Japan, Spain, England, South Korea and Switzerland, were also among the top ten countries publishing solar hydrogen generation articles. Listing publications by organization name, in third column Table 3, shows that the United States Department Of Energy Doe With 10 articles, University of California System with seven articles, at the top institution, followed by Chinese Academy Of Sciences, Royal Melbourne Institute Of Technology RMIT, are the top four solar hydrogen research institutions that have published the most articles on solar hydrogen power during 2001-2014.

\section{Distribution by author, frequency author keyword and funding agencies}

According to the Table 4, there are 67 authors in the world who participated in publications related to solar hydrogen generation research area. The first 10 authors are listed in Table 4 with the number of publication in this area. Prof, Roeb and Sattler with six publication in solar hydrogen generation from Germany has most of the papers, following 
Table 4 Top ten author and funding agencies in solar hydrogen generation

\begin{tabular}{|c|c|c|c|}
\hline Authors & $\mathrm{N}$ & Funding agencies & $\mathrm{N}$ \\
\hline $\begin{array}{l}\text { Roeb (Bak et al. 2002; Agrafiotis et al. 2005; Roeb et al. } \\
\text { 2006; Duigou et al. 2007; Pregger et al. 2009; Roeb and } \\
\text { Müller-Steinhagen 2010; Noglik 2010) }\end{array}$ & 6 & $\begin{array}{l}\text { National Natural Science Foundation } \\
\text { Of China }\end{array}$ & 8 \\
\hline $\begin{array}{l}\text { Sattler (Agrafiotis et al. 2005; Roeb et al. 2006; Noglik } \\
\text { 2010; Noglik et al. 2009, 2011; Graf et al. 2008; Paul } \\
\text { and Andrews 2008) }\end{array}$ & 6 & NSF & 5 \\
\hline $\begin{array}{l}\text { Andrews (Dou and Andrews 2012; Andrews and Shabani } \\
\text { 2012; Shabani and Andrews 2011; Shabani et al. 2010) }\end{array}$ & 5 & $\begin{array}{l}\text { National Basic Research Program Of } \\
\text { China } 973 \text { Program }\end{array}$ & 3 \\
\hline Kanmani (Priya and Kanmani 2008, 2009, 2010) & 4 & $\begin{array}{l}\text { National High Technology Research } \\
\text { And Development Program } 863\end{array}$ & 3 \\
\hline Li (Wang et al. 2013; Wang and Li 2013) & 4 & $\begin{array}{l}\text { National Key Technology Rd } \\
\text { Program }\end{array}$ & 3 \\
\hline Licht (Licht 2002, 2005, 2009) & 4 & $\begin{array}{l}\text { Fundamental Research Funds For The } \\
\text { Central Universities }\end{array}$ & 2 \\
\hline Noglik (Noglik et al. 2011) & 4 & MEST & 2 \\
\hline Pitz-Paal (Noglik et al. 2009) & 4 & $\begin{array}{l}\text { National Basic Research Program Of } \\
\text { China }\end{array}$ & 2 \\
\hline Priya $(2008,2009,2013)$ & 4 & National Dong HWA University & 2 \\
\hline Romero (Z'graggen et al. 2007) & 4 & $\begin{array}{l}\text { National Science Council Of The } \\
\text { Republic Of China Taiwan }\end{array}$ & 2 \\
\hline
\end{tabular}

by Andrews from Australia with five papers. Behind them kanmani, Li Y and Licht are the five top author in this area.

In the third column of Table 4, it is shown that the top funding agencies which funded the investigations on solar hydrogen generation. National Natural Science Foundation Of China with 8 papers is the first among funding agencies followed by NSF with five paper is ranked second, and Natural Basic Science Program China with three papers are the top three funding agencies in field of solar hydrogen.

In Table 5, author keywords that appeared in the articles from 2001 to 2014 were counted with intervals of 5 years. Among all 107-author keywords used, 72 (71\%) keywords appeared only once, $23(21 \%)$ keywords were used twice, and $8(7 \%)$ keywords appeared three times. The large number of one-time-used keywords probably indicates a lack of continuity in research and a wide disparity in research focuses. The most frequently used keyword for all periods was "Solar hydrogen" as it was also a keyword used in this research. During the entire study period, Hydrogen, Solar energy and Water splitting are always the most frequently used author keywords, which indicates that these title are invariable hotspots in the field of solar hydrogen production research. Furthermore, it is worth noticing that limited research has been done before on Photocatalysis, Hydrogen production, and PEM electrolyser. However articles on these aspects have obviously increased in recent years. The number of papers and percentage of which author keywords including solar hydrogen and hydrogen etc.

This indicates that 'information systems attracted more and more attention during the past 14 years, indicating that these words may be a potential new focus in the future. On the contrary, it is surprising to find that there are several popular titles in the past such as Photocatalysis etc. that are becoming gradually less significant as noted during our 10-year study period. 
Table 5 Frequency keyword by author

\begin{tabular}{lrlll}
\hline Frequency keyword & N & $2000 / 2005$ & $2005 / 2010$ & $2011 / 2014$ \\
\hline Solar hydrogen & 25 & 1 & 4 & 20 \\
Hydrogen & 24 & 2 & 6 & 16 \\
Solar energy & 19 & 2 & 5 & 12 \\
Water splitting & 18 & 1 & 4 & 13 \\
Hydrogen generation & 15 & 2 & 4 & 9 \\
Electrolyzer & 13 & 2 & 5 & 6 \\
Photoelectrochemical & 13 & 1 & 4 & 8 \\
PEM electrolyser & 11 & 2 & 4 & 5 \\
Photocatalysis & 10 & 2 & 4 & 4 \\
Hydrogen production & 9 & 1 & 3 & 5 \\
\hline
\end{tabular}

\section{Review the first 10 top papers in field of solar hydrogen generation}

According to Table 6 (see Online Supplement), there are four papers that try to improve efficiency of photo-electrochemical cells by using different material type, three researches on control current and voltage to get maximum power and other papers review the researches done in this field. The result of these 10 top paper shows that in order to improve efficiency of the generation, materials and control the losses on the process must be up to dated. One of the interesting paper, which published in 2008, consider solar hydrogen generation for vehicles with total citation 56 and average citation eight for each year, which published in USA and number of citation each year dramatically increase. In first column Table 6 (see Online Supplement), it is show that 6 paper of 10 top paper published after 2006, in other word, it is clear how this topic become hot topic in this area.

\section{Conclusion}

In this work on solar hydrogen -related papers dealing with the SCI, we obtained some significant points on the global research performance throughout the period from 2001 to 2014. In total, 4681 articles were published in 1918 journals listed in 202 subject categories established by ISI. The solar hydrogen generation presented an upward trend as the paper production increased exponentially in the last 14 years, and the annual paper production in 2013 was about three times that of the paper production in 2010. As the flagship journal of the solar hydrogen generation related field, International Journal of Hydrogen Energy published the most articles. Approximately $22 \%$ of the articles that refer to solar hydrogen generation reside in the 10 core journals, whereby the remainder resides in the other 1908 journals. With the study of national research publications in the last 15 years, the increasing trend in the number of countries worldwide participating in this research can be easily observed. To a certain extent, large numbers of research papers from a country are correlated with the high activity and academic level of the country. It was notable that USA and China, contributing the most independent and international collaborative articles, had the most frequent international partners. Articles with international co-authorship, shows higher visibility than others over the years. The use of several author keywords such as 'solar hydrogen, 'hydrogen 'and 'solar energy dramatically increased since 2007, which became the focus in the last few years, and might be a new research direction in the future. 
There are clear distinctions among author keywords used in publications from the five most productive countries in solar hydrogen research. Quantitative and qualitative analysis used to the development of global scientific production in a specific research field. As solar hydrogen generation has always been thought to be widely useful to energy saving, more efforts should be taken to further studies in these fields.

Acknowledgments The authors gratefully acknowledge the financial support for this work that provided by University Putra Malaysia. I wish to thank Dr. Mahmmod Danaei for comments that helped to improve the manuscript, and for helping to search the literature.

\section{References}

Agrafiotis, C., et al. (2005). Solar water splitting for hydrogen production with monolithic reactors. Solar Energy, 79(4), 409-421.

Andrews, J., \& Shabani, B. (2012). Dimensionless analysis of the global techno-economic feasibility of solar-hydrogen systems for constant year-round power supply. International Journal of Hydrogen Energy, 37(1), 6-18.

Aroutiounian, V., Arakelyan, V., \& Shahnazaryan, G. (2005). Metal oxide photoelectrodes for hydrogen generation using solar radiation-driven water splitting. Solar Energy, 78(5), 581-592.

Bak, T., et al. (2002). Photo-electrochemical hydrogen generation from water using solar energy. materialsrelated aspects. International Journal of Hydrogen Energy, 27(10), 991-1022.

Barbir, F. (2005). PEM electrolysis for production of hydrogen from renewable energy sources. Solar Energy, 78(5), 661-669.

Barbir, F. (2012). PEM fuel cells: theory and practice. USA: Academic Press.

Dicks, A. L. (1996). Hydrogen generation from natural gas for the fuel cell systems of tomorrow. Journal of Power Sources, 61(1), 113-124.

Dincer, F. (2011). The analysis on photovoltaic electricity generation status, potential and policies of the leading countries in solar energy. Renewable and Sustainable Energy Reviews, 15(1), 713-720.

Dou, X. X., \& Andrews, J. (2012). Design of a dynamic control system for standalone solar-hydrogen power generation. Procedia Engineering., 49, 107-115.

Duigou, A. L., et al. (2007). HYTHEC: an EC funded search for a long term massive hydrogen production route using solar and nuclear technologies. International Journal of Hydrogen Energy, 32(10), $1516-1529$.

El-Bassuoni, A., Sheffield, J. W., \& Veziroglu, T. (1982). Hydrogen and fresh water production from sea water. International Journal of Hydrogen Energy, 7(12), 919-923.

Eriksson, S., et al. (2006). Fuel-rich catalytic combustion of methane in zero emissions power generation processes. Catalysis Today, 117(4), 447-453.

Fakioğlu, E., Yürüm, Y., \& Veziroğlu, T. N. (2004). A review of hydrogen storage systems based on boron and its compounds. International Journal of Hydrogen Energy, 29(13), 1371-1376.

Ghosh, P., et al. (2003). Ten years of operational experience with a hydrogen-based renewable energy supply system. Solar Energy, 75(6), 469-478.

Gibson, T. L., \& Kelly, N. A. (2008). Optimization of solar powered hydrogen production using photovoltaic electrolysis devices. International Journal of Hydrogen Energy, 33(21), 5931-5940.

Gorensek, M. B., \& Forsberg, C. W. (2009). Relative economic incentives for hydrogen from nuclear, renewable, and fossil energy sources. International Journal of Hydrogen Energy, 34(9), 4237-4242.

Graf, D., et al. (2008). Economic comparison of solar hydrogen generation by means of thermochemical cycles and electrolysis. International Journal of Hydrogen Energy, 33(17), 4511-4519.

Hensel, J., et al. (2010). Synergistic effect of CdSe quantum dot sensitization and nitrogen doping of TiO2 nanostructures for photoelectrochemical solar hydrogen generation. Nano Letters, 10(2), 478-483.

Kotler, P. (2011). Reinventing marketing to manage the environmental imperative. Journal of Marketing., 75(4), 132-135.

Larminie, J., Dicks, A., \& McDonald, M. S. (2003). Fuel cell systems explained (Vol. 2). New York: Wiley.

Licht, S. (2002). Efficient solar generation of hydrogen fuel-a fundamental analysis. Electrochemistry Communications, 4(10), 790-795. 
Licht, S. (2005). Thermochemical solar hydrogen generation. Chemical Communications, 37, 4635-4646.

Licht, S. (2009). STEP (solar thermal electrochemical photo) generation of energetic molecules: A solar chemical process to end anthropogenic global warming. The Journal of Physical Chemistry C, 113(36), $16283-16292$.

Licht, S., et al. (2001). Over $18 \%$ solar energy conversion to generation of hydrogen fuel; theory and experiment for efficient solar water splitting. International Journal of Hydrogen Energy, 26(7), 653-659.

Linkous, C.A. and N.Z. Muradov, (2001) Closed cycle photocatalytic process for decomposition of hydrogen sulfide to its constituent elements. Google Patents.

Luo, W., et al. (2011). Solar hydrogen generation from seawater with a modified BiVO4 photoanode. Energy and Environmental Science, 4(10), 4046-4051.

Maghami, M., et al. (2014). Impact of dust on solar energy generation based on actual performance. In Power and Energy (PECon), 2014 IEEE International Conference on. IEEE.

Maghami, M., et al. (2015). Evaluation of the 2013 Southeast Asian Haze on Solar Generation Performance. PloS one, 10(8), e0135118.

Momirlan, M., \& Veziroglu, T. (2002). Current status of hydrogen energy. Renewable and Sustainable Energy Reviews, 6(1), 141-179.

Momirlan, M., \& Veziroglu, T. N. (2005). The properties of hydrogen as fuel tomorrow in sustainable energy system for a cleaner planet. International Journal of Hydrogen Energy, 30(7), 795-802.

Motlagh, O. et al. (2015). Knowledge-mining the Australian smart grid smart city data: A statistical-neural approach to demand-response analysis. In S. Geertman, J. Ferreira Jr, R. Goodspeed \& J. Stillwell (Eds.), Planning support systems and smart cities. Lecture notes in Geoinformation and Cartography (pp. 189-207).

Nadal, M., \& Barbir, F. (1996). Development of a hybrid fuel cell/battery powered electric vehicle. International Journal of Hydrogen Energy, 21(6), 497-505.

Noglik, A., et al. (2010). Numerical Optimization of a Volumetric Solar Receiver-Reactor for Thermochemical Hydrogen Generation via Decomposition of Sulfur Trioxide. Proceedings of the ASME 2010 4th International Conference on Energy Sustainability: American Society of Mechanical Engineers.

Noglik, A., et al. (2009). Solar thermochemical generation of hydrogen: development of a receiver reactor for the decomposition of sulfuric acid. Journal of Solar Energy Engineering, 131(1), 011003.

Noglik, A., et al. (2011). Modeling of a solar receiver-reactor for sulfur-based thermochemical cycles for hydrogen generation. International Journal of Energy Research, 35(5), 449-458.

Paul, B., \& Andrews, J. (2008). Optimal coupling of PV arrays to PEM electrolysers in solar-hydrogen systems for remote area power supply. International Journal of Hydrogen Energy, 33(2), 490-498.

Pregger, T., et al. (2009). Prospects of solar thermal hydrogen production processes. International Journal of Hydrogen Energy, 34(10), 4256-4267.

Priya, R., \& Kanmani, S. (2008). Solar photocatalytic generation of hydrogen from hydrogen sulphide using CdS-based photocatalysts. Current Science (00113891), 94(1), 102-104.

Priya, R., \& Kanmani, S. (2009). Batch slurry photocatalytic reactors for the generation of hydrogen from sulfide and sulfite waste streams under solar irradiation. Solar Energy, 83(10), 1802-1805.

Priya, R., \& Kanmani, S. (2010). Solar photocatalytic generation of hydrogen under ultraviolet-visible light irradiation on $(\mathrm{CdS} / \mathrm{ZnS}) / \mathrm{Ag} 2 \mathrm{~S}+(\mathrm{RuO} 2 / \mathrm{TiO} 2)$ photocatalysts. Bulletin of Materials Science, 33(1), $85-88$.

Priya, R., \& Kanmani, S. (2013). Design of pilot-scale solar photocatalytic reactor for the generation of hydrogen from alkaline sulfide wastewater of sewage treatment plant. Environmental Technology, 34(20), 2817-2823.

Raja, K., Mahajan, V., \& Misra, M. (2006a). Determination of photo conversion efficiency of nanotubular titanium oxide photo-electrochemical cell for solar hydrogen generation. Journal of Power Sources, $159(2), 1258-1265$.

Raja, K., et al. (2006b). Photo-electrochemical hydrogen generation using band-gap modified nanotubular titanium oxide in solar light. Journal of Power Sources, 161(2), 1450-1457.

Roeb, M., \& Müller-Steinhagen, H. (2010). Concentrating on solar electricity and fuels. Science, 329(5993), 773-774.

Roeb, M., et al. (2006). Solar hydrogen production by a two-step cycle based on mixed iron oxides. Journal of Solar Energy Engineering, 128(2), 125-133.

Satyapal, S., et al. (2007). The US Department of Energy's National Hydrogen Storage Project: Progress towards meeting hydrogen-powered vehicle requirements. Catalysis Today, 120(3), 246-256.

Shabani, B., \& Andrews, J. (2011). An experimental investigation of a PEM fuel cell to supply both heat and power in a solar-hydrogen RAPS system. International Journal of Hydrogen Energy, 36(9), 5442-5452. 
Shabani, B., Andrews, J., \& Watkins, S. (2010). Energy and cost analysis of a solar-hydrogen combined heat and power system for remote power supply using a computer simulation. Solar Energy, 84(1), $144-155$.

Sherif, S. A., Barbir, F., \& Veziroglu, T. (2005). Wind energy and the hydrogen economy-review of the technology. Solar Energy, 78(5), 647-660.

Sopian, K., et al. (1996). Performance analysis of photovoltaic thermal air heaters. Energy Conversion and Management, 37(11), 1657-1670.

van de Krol, R., Liang, Y., \& Schoonman, J. (2008). Solar hydrogen production with nanostructured metal oxides. Journal of Materials Chemistry, 18(20), 2311-2320.

Veziroglu, T. N. (2008). 21st Century's energy: Hydrogen energy system. Energy Conversion and Management, 49(7), 1820-1831.

Wang, G., \& Li, Y. (2013). Nickel catalyst boosts solar hydrogen generation of cdse nanocrystals. ChemCatChem., 5(6), 1294-1295.

Wang, H., et al. (2013). Self-biased solar-microbial device for sustainable hydrogen generation. ACS Nano, $7(10), 8728-8735$.

Winter, C.-J. (1987). Hydrogen energy-expected engineering breakthroughs. International Journal of Hydrogen Energy, 12(8), 521-546.

Xiong, L., Kannan, A., \& Manthiram, A. (2002). Pt-M (M = Fe Co, Ni and Cu) electrocatalysts synthesized by an aqueous route for proton exchange membrane fuel cells. Electrochemistry Communications, 4(11), 898-903.

Z'graggen, A., et al. (2006). Hydrogen production by steam-gasification of petroleum coke using concentrated solar power-II Reactor design, testing, and modeling. International Journal of Hydrogen Energy, 31(6), 797-811.

Z'graggen, A., et al. (2007). Hydrogen production by steam-gasification of petroleum coke using concentrated solar power-III. Reactor experimentation with slurry feeding. International Journal of Hydrogen Energy, 32(8), 992-996.

Zhang, Y.-H. P., et al. (2007). High-yield hydrogen production from starch and water by a synthetic enzymatic pathway. PLoS ONE, 2(5), e456. 